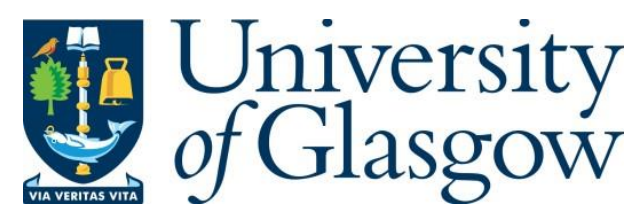

Anderson, S., Tonner, A. and Hamilton, K. (2017) Death of buildings in consumer culture: natural death, architectural murder and cultural rape. Consumption Markets and Culture, 20(5), pp. 387-402.

There may be differences between this version and the published version. You are advised to consult the publisher's version if you wish to cite from it.

http://eprints.gla.ac.uk/135263/

Deposited on: 24 January 2017

Enlighten - Research publications by members of the University of Glasgow http://eprints.gla.ac.uk 
Death of buildings in consumer culture: natural death, architectural murder and cultural rape 


\begin{abstract}
We propose that focusing on the death of buildings has much to offer in terms of our understanding of consumer culture. The aim of this paper is to explore the death of buildings from the perspective of consumers who have an interest in exploring obsolete buildings. Drawing on an ethnographic study of urban exploration, we uncover consumer understandings of death and mortality. We make a number of contributions. First, we demonstrate how death terminology is appropriate to material culture. Second, we reveal how consumer fascination with derelict buildings opens up opportunities for otherwise suppressed thoughts and conversations about death. Third, we recognise the multidimensional nature of death and introduce the concept of cultural death in consumer culture.
\end{abstract}

Keywords: death, buildings, ethnography, consumer culture, urban exploration 


\section{Death of buildings in consumer culture: natural death, architectural murder and cultural rape}

\section{Introduction}

"Buildings are more like us than we realise. They can be born into wealth or poverty, enjoying every privilege or struggling to make ends meet. They have parents - gods, kings and emperors, governments, visionaries and madmen - as well as friends and enemies. They have duties and responsibilities. They can endure crises of faith and purpose. They can succeed or fail. They can live. And, sooner or later, they die” (Crawford 2015).

This opening quotation is taken from the overleaf of Crawford's (2015) 'Fallen Glory' which outlines the biographies of 20 lost buildings that have become part of our collective memory such as the Twin Towers, the Berlin Wall and the Tower of Babel. The stories of the death of these buildings not only have architectural significance but also open up cultural accounts of key moments in history. Following Crawford's (2015) lead, we propose that focusing on the death of buildings also has much to offer in terms of our understanding of consumer culture.

The aim of this paper is therefore to explore the death of buildings from the perspective of consumers. We uncover these consumer understandings through an ethnographic study of urban exploration. Urban exploration involves the discovery and exploration of restricted and derelict buildings (Garrett 2011). These buildings are less iconic than those considered by Crawford (2015) but are nevertheless meaningful to urban explorers. Consumer research surrounding death tends to prioritise the death of people and focuses on issues such as bereavement (e.g. O'Donohoe 2015), possession disposition through gifting (e.g. Turley and O’Donohoe 2013) or death rituals (e.g. Hackley and Hackley 2016). By exploring death within 
an alternative context, we address the following research questions: What do consumers understand of death within material culture? How do derelict buildings shape consumers' understanding of death and mortality? How does the death of buildings inform our understanding of consumer culture?

Although waste is "an inevitable consequence of consumption" (De Coverly et al. 2008, 295) that occurs when objects fall into disuse and obsolescence, waste and disposal have attracted less research attention than other elements in the consumption process (Benton 2014; Parsons and Maclaran 2009). By considering derelict buildings through a death studies lens, we open up this field of enquiry and make a number of contributions. First, we demonstrate how death terminology is appropriate to material culture. Second, we reveal how consumer fascination with derelict buildings opens up opportunities for otherwise suppressed thoughts and conversations about death. Third, we recognise the multidimensional nature of death and introduce the concept of cultural death in consumer culture.

The article is organised as follows. First, we review relevant literature on the life and death of buildings. Next, we discuss derelict places as modern ruins of the recent past including an overview of urban exploration to better contextualise the study. We then detail the methods of data collection and analysis. Findings are organised around three central themes that emerged from our data: physical death for buildings and the process of dying, cultural death and its associated feelings of loss, and a good death for buildings. Finally, we discuss the contributions arising from our research for understanding death in consumer culture.

\section{The life and death of buildings}

Appaduari (1986) asserts that objects have social lives as they move through biographies and experience changes in their commodity status. A once cherished object can 
move into disuse, towards waste and eventual disposal after the owner's death. Buildings may exhibit such biographies as they evolve over time, for example, Maclaran and Brown (2005) illustrate how refurbishment changed the meanings associated with a festival shopping mall. Hollis' (2009) aptly titled 'The Secret Lives of Buildings' epitomises this perspective and is based on the premise that "buildings are designed to last, and therefore they outlast the insubstantial pageants that made them. Then, liberated from the shackles of immediate utility and the intentions of their masters, they are free to do as they will." This suggestion of the agency of buildings is also revealed in the vocabulary of architecture that brings buildings to life through bodily (e.g. building structures described as bones) and spiritual (e.g. the building's soul) metaphors (Cairns and Jacobs 2014).

The emerging debate on vital materialism has drawn attention to the vitality of objects as flows of materiality, and to the agentic powers of both human and non-human things (Bennett 2004). Consumer researchers have recognised the agency of objects, for example, Lim and Fitchett (2011) argue that modern day societies are characterised by death-fearing culture where the death-disposal of objects gives consumers anxiety. They conceptualise death objects as the possessions left behind or orphaned by the deceased and suggest that death objects have an agentic permanence and presence beyond the mortality of their owners. Similarly, Baker et al. (2016) demonstrate the sense of permanence and inalienability associated with bodily remains and a person's final resting place given the role this plays in the ongoing family story. Further Epp and Price (2010) demonstrate that valued objects threatened with displacement due to changes in family circumstances can be granted agency to be reincorporated and reengaged into networks of use. Arguably, buildings may have equal agency with Crawford $(2015,3)$ contrasting the "epic" lives of buildings that can last for thousands of years against human's limited lifespans. 
Despite their potential durability, the ultimate fate of buildings is inevitable as evidenced in Cairns and Jacob's (2015) 'Buildings Must Die.' The authors draw attention to the death, destruction and deterioration of buildings as often overlooked alternatives to permanence and endurance. They argue that under capitalism the fate of buildings is determined by the market and draw on David Harvey's $(1975,124)$ description of "perpetual perishing" to highlight how architecture is linked to destruction whereby buildings can only be saved if aesthetic or historical value is strong enough to prevail over market value. Referring to the post-industrial city, Miles $(2010,77)$ suggests that "architecture is actively mobilised in order to reproduce a myth of urban vitality." This sense of urban vitality is supported by retailers and urban planners whose efforts concentrate on "animating the urban experience" and offering experiential spaces for consumption (Warnaby 2013, 29). However, less attention is given to what happens when buildings no longer fulfil this function.

The process of decay is fickle as different rates of decomposition completely erase materials whilst others remain (Edensor 2005b), creating a 'temporal collage' (Lynch 1972). Gregson, Watkins and Calestani (2010) illustrate that materials are animate and performative in the processes of disposal and recycling due to their ability to transform, morph and mutate into other states. The vitality of materials is most profound in the processes of decay where objects degrade and transform. This is reflected in Taussig's (2003, 15-16) account of decay in bogs and swamps where life and death are suspended "between a miraculous preservation and an always there of immanent decay." Decay disrupts the linearity of memory as it causes temporalities and materials to intersect, collide and merge through decomposition: "decaying buildings extinguish and reveal successive histories as layers peel away and things fall out from their hiding places" (Edensor 2005b, 834). 


\section{Derelict buildings: modern ruins of the recent past}

Since the rise to popularity in the $18^{\text {th }}$ century ruins have historically been admired for their sublime grandeur and wild desolation (Shanks 2014). Throughout history ruins have been understood as signifying displacements of time, space and being. Indeed Simmel $(1959,265)$ considers the ruin as a remnant of past life and a signifier of death in describing it as "the site of life from which life has departed...the present form of past life." Diderot described his experience of walking amongst ruins as being “between two eternities" (1995 [1767], 196). For Augé (2003) this demonstrates the ruin's capacity to disturb linear notions of time. Benjamin (1999) furthers this notion of disjuncture by suggesting that ruins have the potential to exist as a dialectical image that haunts the present with an abandoned future. This relates to Derrida's (1994) notion of hauntology as an alternative ontology that displaces the importance of being and presence by drawing attention to the 'specter', that is neither present, absent, dead or alive (Laclau 1995). Derrida (1994) considers the endurance of certain historical events and notions as examples of hauntology, whereby revenants from the past are stuck in a continuous limbo of being and non-being, never fully coming into fruition in the present day. Relating this to understandings of consumption, Edensor (2005c) posits that ruins exist in a state of indeterminacy, jointly absent and present in a state of 'unfinished disposal' (Degen and Hetherington 2001), in limbo between rejection and obliteration.

Contemporary understandings of ruins are ambiguous and contested (Pétursdóttir and Olsen 2014). This has been furthered by the variety of ruin terminology; authentic ruin (Huyssen 2010), romantic ruin (Ashurst 2007), heritage ruin (Pétursdóttir 2012), industrial ruin (Edensor 2005a), and modern ruin (Pétursdóttir and Olsen 2014). Modern ruins of the recent past are rarely granted the same fascination, admiration or protection by heritage agencies because of their historical immaturity and rotting state they are "caught up somewhere between disposal and history" (Pétursdóttir 2012, 33). For Apel (2015) the appeal of historical ruins is 
rooted in Romanticism whereas the contemporary fascination with modern ruins is driven by anxiety of capitalism. Following the product life cycle, once buildings have lost their functional use, they subsequently lose value and become considered as waste (Edensor 2005c). In contrast, the heritage ruin is a disciplined, sanitised and purified space that is devoid of natural and modern intrusions (Edensor 2005a). Despite this terminological diaspora ruins are generally viewed as outcomes of destruction (Stoler 2008), societal or architectural failure (Crawford 2015), costs of consumerism (Pétursdóttir and Olsen 2014) and the consequences of capitalism (Edensor 2005a). This is most evident in North American cities where economic instability, deindustrialisation, the collapse of Fordism and rise of neoliberalism (Apel, 2015) has created "a ruin landscape" (Pétursdóttir and Olsen 2014, 4983) that is littered with empty factories, derelict shopping malls, and redundant mining towns. Detroit has become the focus of this social critique and Leary (2011) argues the cultural fascination with Detroit's ruins is a lament for $20^{\text {th }}$ century history and culture, and a social anxiety about the future. Indeed urban studies highlight the creative destruction of cityscapes as an inevitable outcome of capitalism, such as Manhattan slum clearances (Page 2001), Les Halles' marketplace destruction (Wakeman 2007) and Singapore's waterfront regeneration (Chang and Huang 2005) which represent intentional reconstructions of social history, collective memory and a silencing of local memory. In addition to physical, social and symbolic losses, Apel (2015) and Leary (2011) critique ruinphilia for romanticising serious social problems and economic failure that demoralises residents and sensationalises austerity and poverty.

Whilst much literature points to the negativity of ruins as failure and false progression, the rise of ruinophilia, ruin porn and urban exploration imagery has rekindled the $18^{\text {th }}$ century cultural fascination with desolation and ruination. Indeed the increasing allure or schadenfreude of societal misfortune shares some common ground with dark tourism. Lennon and Foley (2000) define dark tourism as any tourist experience associated with death and 
distress. Locations of dark tourism include war museums and memorials (Stone and Sharpley 2008), battle sites (Strange and Kempa 2003), locations of famous deaths (Alderman 2002; Rojek 1993), disasters and social atrocities, such as the World Trade Centre terrorist attack, and the Holocaust death camps (Beech 2000). Dark tourism has become increasingly commodified (Stone 2012) where sites are staged to create spectacular narratives. For example, Chronis, Arnould and Hampton $(2012,269)$ demonstrate how Gettysburg is staged as a place that is characterised by death, sacrifice, defeat and loss. As such, drawing on Godfrey and Lilley (2009), Gettysburg may become a regime of memory rather than a regime of truth.

Despite its historical origins (Seaton 1996; Edwards 2016), much research has suggested the growing fascination with death is a post-modern phenomenon (Muzaini, Teo and Yeoh 2007; Foley and Lennon 1996). Hartman (2014) attributes the recent rise in dark tourism to social and political turbulence whereas Ashworth and Issac (2015) suggest it reflects a general rise in leisure and heritage and could be an outcome of increasing scholarship attention.Research suggest that consumers use dark tourism in various ways; to alleviate the impact of death and enable exposure to violence and taboo (Stone and Sharpley 2008; 2013), to learn about history (Biran, Poria and Oren 2011), to co-create and express a national identity (Tinson, Saren and Roth 2015), to simulate affective states (Podoshen 2013; Ashworth and Issac 2015) and experience unmediated reality reflecting a cultural fascination with dystopia and disaster (Podoshen et al. 2015).

In contrast to places of dark tourism, urban exploration is the discovery and exploration of restricted and derelict places in the built environment that are not publicly accessible (Garrett 2011). This restriction distinguishes urban exploration from dark tourist activities that typically have permission-based access provided by tourist agencies. Like street artists that appropriate public space as a shared public good (Visconti et al. 2010), urban explorers do not own these place but rather they engage in recreational trespass (Garrett 2013). Urban exploration involves 
complex practices of researching place histories, discovering access to sites and the physical exploration of urban relics. Urban explorers also act as archivists by textually and photographically documenting the history and decay of these often forgotten urban places which they share with global online community forums.

The late urban explorer Jeff Chapman (aka Ninjalicious) documented the growth of the subculture of urban exploration and traces its roots from Philibert Aspairt's exploration of the Parisian catacombs in 1793 through to the San Francisco Suicide Club and the Cave Clan (Ninjalicious, 2005). This has renewed the alternative aesthetic appreciation of decay which has appeared in a number of art exhibitions such as Tate Britain's 'Ruin Lust' in 2014 that displayed traditional to present-day ruin art, and the Resistance Gallery's 2010 exhibition of 'Beauty in Decay' that featured urban explorer photography.

\section{Method}

Our findings are based upon a multi-method ethnography that utilises a variety of techniques including ethnographic interviewing, netnography, observant participation, fieldnotes, photography, and researcher diary. This range of collection techniques allowed the researchers to gain a holistic understanding of the practices and experience of urban exploration. Initially the first author became embedded within the online context of urban exploration through a one-year netnography of both discussion forums and personal webpages that were identified as "relevant, active, interactive, substantial, heterogeneous, data-rich, and experientially satisfying" (Kozinets 2015, 175). This involved following specific discussion threads and regular monitoring of personal websites and social networking pages for textual and visual reports of explorations. Importantly, the netnography also facilitated contact with urban explorers who were invited to participant in an interview. Our findings within this paper 
primarily draw on interview data. However, the netnography and other ethnographic materials contribute to our understanding and interpretation of the interview texts.

Ethnographic interviewing seeks to gain richer understanding of consumers' experiences by locating the interview process within the consumption context (Heyl 2008; Holt 1997) by means of a friendly conversation (Spradley 1979). Where possible, interviews were conducted at site locations. This face-to-face visualisation was important to build rapport, but also to allow the use of auto-driven photo elicitation (Heisley and Levy 1990), where the participants displayed and discussed their own exploration photographs during the interview. Given the geographical spread of our sample, some interviews were conducted over videocalling.

Table 1: Participant Details

\begin{tabular}{|l|l|l|l|l|}
\hline Participant & Age & Gender & Country & Occupation \\
\hline Josh & 38 & Male & UK & Artisan bike designer \\
\hline Abby & 23 & Female & Germany & Postgraduate student \\
\hline Matt & 25 & Male & UK & Postgraduate student \\
\hline Sam & 27 & Female & UK & Travel writer \\
\hline Pete & $30 \mathrm{~s}$ & Male & UK & Government worker \\
\hline Andy & 21 & Male & UK & Sportsperson \\
\hline Connor & 25 & Male & UK & Computer technician \\
\hline Mila & $30 \mathrm{~s}$ & Female & Germany & Freelance writer \\
\hline Rory & $30 \mathrm{~s}$ & Male & UK & Professional photographer \\
\hline Simon & $30 \mathrm{~s}$ & Male & UK & Mental health practitioner \\
\hline Hannah & 22 & Female & Germany & Undergraduate student \\
\hline William & 52 & Male & UK & Disability support worker \\
\hline Euan & 40 & Male & UK & Freelance building surveyor \\
\hline
\end{tabular}




\begin{tabular}{|l|l|l|l|l|}
\hline Liam & 38 & Male & UK & Manufacturing technician \\
\hline Nick & 33 & Male & UK & Events manager \\
\hline Lydia & 50 & Female & UK & Magistrate \\
\hline Ariel & 29 & Female & UK & Historian writer \\
\hline Paul & 40 & Male & UK & Professional photographer \\
\hline Luke & 32 & Male & UK & Mechanical engineer \\
\hline Nate & 26 & Male & United States & Advertising producer \\
\hline Seb & 26 & Male & Italy & Professional Photographer \\
\hline Ross & 38 & Male & UK & IT technician \\
\hline Rob & Late $40 \mathrm{~s}$ & Male & UK & Business executive \\
\hline Lexi & 32 & Female & Germany & Professional photographer \\
\hline Max & 40 & Male & Netherlands & Sales Manager \\
\hline Aaron & 36 & Male & Canada & Sales executive \\
\hline Tom & 40 & Male & Canada & Advertising executive \\
\hline Jack & 35 & Male & UK & Self-employed contract \\
cleaner
\end{tabular}

Twenty-eight experienced urban explorers were interviewed (see Table 1). Interviews

followed a semi-structured approach covering broad topic areas such as exploration practices and equipment, attachment to places of urban exploration, documentation of explorations, and online community interactions. Interviews lasted between 90-120 minutes. As advocated by Holt (1997), emic terms created by the participant were probed to elicit deeper understandings of their grounded meaning. All interviews were audio recorded and transcribed in full, generating 630 pages of data.

Data analysis followed an iterative process, allowing the researchers to move back and forth between emic terms and etic theorisation. Applying Glaser's (1965) constant-comparative method, intertextual similarities and differences across the data set were identified. We focused 
on identifying recurring ideas and also explored any alternative or negative cases (Miles and Huberman 1994). This process led to the death of buildings emerging as an important theme which we unpack in the following section with the support of appropriate concepts from the death studies literature.

\section{Findings}

We present our findings in relation to three key themes: an examination of the physical death and the process of dying for buildings, an exploration of cultural death and its associated feelings of loss, and finally a discussion of what constitutes a good death for buildings.

\section{The physical death of buildings and the process of dying}

Participants often associate the physical death of buildings with the intrusion of nature, which reclaims places through the processes of decay, water ingress and dry rot. Once nature, like a parasite or cancer, takes a hold of a building participants anticipate its physical death and like the family of the terminally ill begin to adjust to its demise, as Rob demonstrates:

Certainly the vines growing internally, and it doesn't take long, it doesn't take much. Unfortunately when nature does get into the buildings it doesn't take long for it to take over as well as destroy the building at the same time. So you feel a nervousness when you start seeing - depends on the level of nature in there - how long the place has got left. (Rob) In an interdisciplinary analysis of mortality, Connolly (2011) considers the ruin as a representation of dying in material culture. Death can be sudden or expected, just or unjust, intime or off-time (Carr 2012). Like people who die expectedly, justly or in-time following a long illness or in old age, buildings often experience a prolonged physical demise, slowly losing the characteristics and vitality which distinguished them in life.

While many participants felt that nature (as a living thing in its own right) was virtuous through its beauty, its intrusion into buildings was bittersweet since it simultaneously attacks 
the integrity of the building causing its physical death. Lorimer and Murray $(2015,60)$ term this as the ruin paradox whereby there are conflicting desires for the ruin to remain but also to be left to "Rot in Peace". This ruin paradox is captured in Mila's comments:

Yeah somehow you are sad about it but somehow you are happy that they have gotten in that state. It is a kind of contradiction so...yeah it is difficult. Somehow you are happy about these places, and you want them to stay there like that but they cannot stay in the same state because they will get more rotten and they will just fall apart one day which is also sad, but that is life, the circle of life. (Mila)

Crawford (2015) discusses how the intrusion of nature can be so extensive and complete that determining the presence or existence of the pre-existing building becomes difficult. Mila highlights that physical death in these circumstances, as in terminal illness is an inevitable end. Similar to Gregson et al. (2010), her discussion highlights the process of dying as a continuous change in material states that will result in the building physically disintegrating. Many other participants also associated this decaying process with dying where at one point the building will be physically gone. This is illustrated in Lydia's acceptance of the impermanence of even the most epic buildings.

I think that moment in time when it is sort of decaying and beautiful is great but nothing lasts forever and there is always going to be that moment when we just have to let go of them. Sad though it is. But that is when you want people like me taking photos that we can look back on and just remind ourselves of just how stunning they were in their hey-day, or not even in hey-day, at that point when they were starting to fade away. (Lydia)

This acceptance of death was reflected amongst all participants. Seeing the building over time change and deteriorate may, like the family of those with chronic illness, allow the urban explorer to experience a "quasi-widowhood" before the actual death occurs (Carr 2012, 191). In human death family members may become susceptible to "habituated grief" (Carr 2012, 191). While urban explorers do not experience the same intensity of loss as in human death, 
they do adjust or "habituate" as they witness the decline of the building. Indeed the activity of urban exploration appears to offer individuals an appreciation of the impermanence of life and inevitability of death.

Josh offers a further insight into the point of a building's terminal demise and his pragmatism sets aside the sentimentally of saving buildings and considers the sheer cost and ability of contemporary society to save these dying buildings. In doing so, he reflects ongoing debates in historic preservation which suggest that preservation is only one part of urban planning (Ryberg-Webster and Kinahan 2014).

In some ways it is a pity because....you have to be pragmatic. These buildings, once they get to a certain stage, especially once the water starts getting into them, then saving them becomes incredibly expensive. Nobody in their right mind is really going to throw millions and millions of pounds in saving a really old building, when they could just demolish it. (Josh)

Participants often stressed that each building has its own individual fate that is dependent on its particular physical condition, cultural importance or potential cost for redevelopment, as Crawford $(2015,388)$ suggests "survival alone does not equate with significance. Indeed sometimes it is a site's very obscurity that explains its preservation." However, such ruins may be considered as between life and death, like people who are "in a permanent vegetative state are irreversibly unconscious, yet they are not considered dead" (Truog and Miller 2014, 886) so these buildings retain a physical status which falls short of their ultimate death. In the medical discipline Bury (1982) terms this loss of healthy functioning as biological disruption whereby chronic illness causes individuals and their social networks to consider pain and suffering as potential reality that changes everyday life experience. A building experiences biographic disruption once it has fallen into disuse and is left derelict.

For some such buildings urban explorers often wish for an end to their 'suffering'. In common with human illness, treatment withdrawal is difficult and challenging for family 
members however it is rendered more straightforward when families perceive that it will end suffering (Coombs 2015). For buildings, participants talk about this terminal point coming when they can no longer realistically be saved. This is captured by Rory's discussions of 1960s high-rise flats where he claims: "But yeah what can you do with these flats? It is too late for a lot of them, it is too late and it is too far gone."

As such, we contend that the physical death of a building occurs once physical integrity of the structure rots, the cost to save it outstrips its apparent value and its condition is terminal in that there is no realistic chance of saviour. This reflects economic studies of historic preservation which suggest that cost-benefit analysis underpins decisions to preserve (RybergWebster and Kinahan 2014). It remains difficult to determine the specific moment of a building's death, however, urban explorers mourn yet accept the inevitability of the building's ultimate demise when its physical integrity begins to erode. For urban explorers, physical death is also accompanied by cultural death.

\section{Experiencing loss at a building's cultural death}

Although there is no universal perspective on what death entails, it is often associated with loss and grief. Urban explorers reflect on buildings that no longer exist in their original material form due to natural collapse, demolition or redevelopment with anger, grief and a sense of "melancholy" and "sadness" (Paul). As Crawford $(2015,3)$ discusses, "we care about buildings - sometimes more than we care about our fellow human beings." For participants these losses were most starkly felt when considering buildings beyond their materiality to reflect upon the various cultural demises they represent.

\section{Cultural obsolescence}


In the consumption cycle a product enters the stages of disposal when it no longer has its original use or it has become obsolescent (Hetherington 2004). Participants recognise this movement in a building's use to disuse as the first cultural loss experienced in dying buildings; an inevitable force caused by social and cultural progression. So as Cairns and Jacobs (2014, 103) suggest these obsolete buildings become "in place but out of time." For Luke it is the progression of technology that has dealt the ultimate fate to many buildings as their original use becomes unnecessary in contemporary consumer culture:

It is a shame that they do decline but it is the way that it is going. It is like cinemas shutting down because of Netflix and things like that. You don't have to leave your house. I do think that the internet and things like that obviously, it has got a decline for everything. (Luke) In reflecting on the demise of Whittingham Asylum in 2015, Luke acknowledges that the specificity of the original use of some buildings impedes their ability to be saved or regenerated, trapping them as relics of another time at odds with contemporary practicalities and sensibilities.

At one time it was the biggest asylum in Europe. I think there were like three and a half thousand patients. It is...it is...I'm trying to think of a word. It is, well I am going to say crazy that it is got to that state that they couldn't find a use of it but some things are hard to use...Inevitably some places have to go. [...] It is an absolutely massive site and they knocked it all down for 650 homes. (Luke)

Whilst Luke appreciates the physical and often social difficulty in altering the use of a building, his assertion that it was "crazy" an alternative use could not be found highlights his sense of astonishment that buildings cannot always be saved or transformed into a new use. However, Luke's acceptance of the inevitable loss of buildings reflects Edensor's (2005b, 829) argument that ruins are a product of capitalism - "marginal sites which continue to litter the increasingly post-industrial cities of the West, now bypassed by the flows of money, energy, people, and traffic within which they were once enfolded." Further some of these sites (such as 
Whittingham Asylum) are so tied to their original use, which no longer fits with contemporary culture, that they cannot be exorcised of this past and repurposed. However, whilst many participants demonstrate acceptance they also experience feelings of deep sadness that this is the case.

That is when I get really sad when people can't be bothered to do that little bit of extra hard work to save something that the past has given us as a gift and instead they knock it down, or they leave it empty, or they put up something that has got no character about it and it will be pulled down again in another fifteen, twenty, thirty years' time anyway because its purpose has run out. (Ariel)

For Ariel, buildings are gifts from the past, imbued with meaning that should be cared for and cherished. Ariel's sadness is directed towards the loss of these historical gifts but also towards the continual shortening lifespans of buildings and accelerated cycles of loss that occur as buildings become more disposable once their purpose has run out.

\section{Cultural places}

Buildings are often representative of particular episodes of cultural history (Crawford 2015; Edensor 2005b) and participants voice their sadness at this loss. This is visible in Ariel's comments on the planned demolition of Haslar Hospital, which was used to treat injured soldiers from HMS Victory during the battle of Waterloo.

Especially for somewhere that is historically important. Such as a place like Haslar Hospital, they are going to knock it down and build houses there. They are knocking down a massive piece of Britain's navel history. [...](Ariel)

Ariel's account of Haslar Hospital has historical importance as a site of collective memory. Other participants discuss the neglected mundane places in their local communities that do not share such spectacular historical importance but are nonetheless culturally and socially important. Luke gives the example of a local outdoor sea-water swimming pool. Now derelict, 
Luke considers this to be a loss of "so many memories of what it once was." This reflects the loss of individual memory and subjective recollections that anchor human experience (Chang and Huang, 2005). Whilst Ariel and Luke's accounts reflect different registers of memory, both are at risk of social amnesia and collective forgetting (Schwartz, 2009). The loss of these sites is mourned especially by participants because they sit in contrast to museums where cultural memory becomes fixed through sanitisation. These derelict buildings represent a loss of more complex and contrary voices which have potential to disrupt dominant ways of seeing and being (Edensor 2005b).

Similarly, Sam talks about the loss of local factories and mills in Oldham.

There is a mill in Oldham and it is a listed building. It is going to eventually get demolished. It is a shame because all that will end up happening is eventually it will get knocked down and they will build a set of homogenous flats there or just new-build houses and people will just forget that there was this big important building there. I mean look at it, it is obviously not as beautiful as that [points to the city halls], but that is the history of the city, of the town. (Sam)

For Sam, the loss of these industrial ruins has particular cultural importance to the local history of the region. Sam is further saddened at the thought that people will forget about these once culturally importance places of work and community when they have been demolished and replaced by housing. Despite the lack of grandeur and spectacle, these buildings have been compared to cherished public buildings. Although the use of these places precedes participants' personal experiences, they still consider the demise of these buildings as a personal loss to their cultural heritage. Drawing upon Hill and Cromatie's (2004) assertion that we are passively tethered to out past, Podoshen and Hunt (2009) demonstrate that consumers can be impacted by events that precede their lifetime due to cultural and ethnic ties through collective memory. 
As such, our participants' sense of cultural loss is embedded in the collective memory of the regions' past events.

\section{Cultural skill}

Participants also mourned the loss of the architectural craftsmanship that is often found within these buildings. For many, disregard of such features represents a larger cultural trend of disposability, "throwaway society" (Paul) and "wasteful race" (Ross).

I think we live in a throwaway society nowadays. Buildings they are not like the grand architecture like it was back in the day. There is no woodwork and fancy architecture. It is just like all MDF and bricks. It is not what we used to have in the past. That is why I love it. I love seeing that before it is gone. Once it is gone, it is gone. (Liam)

For Ross, even the redevelopment of a building can involve cultural loss if important architectural features are removed, covered up and erased from the building's fabric. This reflects Starn's (2002) discussion of how authenticity may be lost as preservation changes the nature of the buildings, creating a false authenticity or inauthentic truth:

I would rather they were used for absolutely anything to be honest, as long as they don't tear the heart out of the place by taking out all of the décor. Most of them unfortunately get changed into flats. It's like a lot of churches, there seems to be a bit of a fashion for people building up old churches and turning them into flats, apartments but then they hide all of the features behind plasterboard walls. All the stained glass would be covered up and it just lost the heart and soul of the building. (Ross)

More than cultural importance, Ross regards the decorative materials as the "heart and soul" of a building, and without them, as in the brain death of people, the building has lost its “integrated functioning” and original character (Truog and Miller 2004, 886). Ross imbues human qualities to buildings that illustrate the connection he feels towards these often neglected relics. 
Associated with the loss of these architectural features is the loss of the skills required to create them. This cultural death is particularly evident in Paul's account where the finality of a building's demise often means that the ornate interiors and skills to create them die with the buildings themselves.

These buildings that they are leaving to crumble are buildings that people had put so much effort, and time and money into. They are absolutely gorgeous you know. These are the buildings that mill owners used to build to show off how much money they had. They would put...they are so ornate and they just don't make them like that anymore. I just think that we are losing that too quickly. We are losing it and nobody is trying to replicate it. (Paul)

This concern was present throughout participants' responses captured by Rob's discussion of Victorian brickwork: "That craftsmanship is not about anymore." As such, the loss of these buildings often represents a larger societal change where some skills are no longer necessary. Rob elaborates on this premise:

We are just missing so many opportunities and a lot of these [buildings] are just falling into disrepair. The workmanship and the class of master shipbuilding is gone. We look at nowadays there are no apprentices for stone masonry and carpentry. You are just a joiner who makes something out of a piece of wood that has already been pre-fabricated, bricks are done on a kiln, they are not done out of a stone quarry. There is something there that has just been taken away and one day we will just lose it all. (Rob)

Rob highlights the generational legacy of craft work which has in some cases experienced a cultural death as it is no longer needed in modern buildings. The finality of his assertion that "one day we will just lose it all" demonstrates the severity and weight of this cultural loss as a non-returnable end for many skills and crafts. Adding another layer to the notion of cultural death William highlights the "brutality" of cultural loss.

When I was a kid buildings never meant much to me. The world was a big dark place. But now looking at it in the clear light of day, all of these old Victorian places the craftsmanship 
that went into them was unbelievable. Another thing is the brutality of just dismissing them and getting rid of them for land is culturally quite bad for me now. I think these places could be saved. I think they could be kept in a way that we respect what they used to be. Whereas they just keep the facings of them. That is taking the heart. (William)

Like Ross, William considers buildings to have a heart in their original use and material integrity. For William, neglecting, dismissing and destroying buildings is a brutal act on culture and evokes imagery of murder and mutilation. In this case cultural death has a sense of mistreatment and violence.

\section{A good death for buildings}

Once diagnosed with a terminal illness the notion of a good death (Aries 1974; Seale and van der Geest 2004) is viewed to be the preferable outcome. Much like a person, participants hold notions of good and bad deaths for buildings and reflect a preference for a peaceful death. In particular Simon draws on the notion of a natural death to discuss ruins where nature has taken control.

I think they should just be left as they were... Maybe someone will come to it who owns it, but until then just let it rest in peace I guess. [... I would like for them to stay there and whatever happens to them happens to them through nature. If they end up blowing over and crumbling then that is what is meant to be. (Simon)

For Simon, letting buildings "rest in peace" means trusting in fate to deal "what is meant to be." Even though Simon would like these places to remain he finds this natural demise easier to accept, reflecting an aesthete's view of preservation (Starn 2002). Lydia offers similar sentiments in her discussion of the Maunsell Sea Forts:

If you take those sea forts out in the sea for example they are actually trying to raise money to turn it into a high-end hotel. So at the moment you have got this beautiful decaying lump of rust, which potentially in five years could be a very swish modern looking hotel. Whether 
it will happen is another matter because it will be a feat of engineering and it will take a huge amount of money. I have got mixed feeling about that. Personally I would like to see it fall into the sea and just die gracefully. Likewise I just think that some buildings are just so far gone we should almost just let them fade away. Restoration is a wonderful thing isn't it, if it is done beautifully and for good reasons. I like to see the buildings just left in peace to be honest. (Lydia)

Despite the potential for redevelopment Lydia would prefer a natural death for the Maunsell Sea Forts as she believes they are past the point of saving. Her sentiments of "die gracefully", "fade away" and "rest in peace" offer an understanding of a good death for buildings. Nature is left to take its course, rejecting restorative treatments, such as sandblasting or underpinning which are likely to have little impact in the same way that the terminally ill often don't wish for intrusive resuscitative interventions (Miljković et al, 2015). This runs counter to Lorimer and Murray's $(2015,61)$ assertion that " $[\mathrm{r}]$ ot is a process that sits uneasily with the image of a peaceful end." Instead a peaceful death for buildings allows nature to ravage the structures returning their once monumental stature into the earth.

In contrast to the good peaceful death from natural causes, participants understand a bad death or a "sad ending" (Jack) to be caused by human agency. Families who experience sudden, unjust or off-time deaths often find these more difficult to grieve (Carr 2009). Crawford (2015) reflects this in his discussion of the sudden, unjust and off-time destruction of the World Trade Centre and the 'void' left behind. Similarly, participants often cite metal thieves, vandals and owners to cause the majority of damage within derelict buildings. Indeed, the strength of this feeling is captured in William's comments on demolition and arson by owners to illustrate the abuse that buildings experience before their demise.

There are other times that they deliberately get stuff set on fire. I find that dreadful because it is a cultural thing for me. They are burning my history. [...] The cultural aspect, to me the 
place has just been culturally raped. That is the way that it is. I have never known so many buildings getting pulled down and suspicious buildings going on fire. (William)

For William, arson is a cultural abuse akin to the violence and inhumanity of rape. His assertions viscerally illustrate the violent pillage and stripping away of history and heritage in cultural death. In an examination of images of catastrophe, Kaplan (2008) introduces the notion of witnessing whereby an individual is transformed by an image of trauma. In particular, we see evidence of witnessing in William's assertion that "they are burning my history" affirming this notion of witnessing a traumatic event that is felt by the individual as a personal loss or suffering. In her discussion of demolition Ariel expresses the horror and violence when people take control over physical death.

We have respect for the buildings and we have absolutely no respect for the people who have let them fall into the state of decay that they have fallen into, at least I don't anyway. [...] I called it architectural murder. In some respects depending on the state of the building it can also be architectural euthanasia but in a lot of cases a building can be saved (Ariel)

Compared with the peacefulness of the good death, Ariel's choice of "murder" highlights the physical brutality and violent end to some buildings' lives. However, she also suggests that human intervention with the inevitable fate of physical death through euthanasia can relieve suffering. In many respects this demonstrates consumers' empathy with the building. Whilst dark tourists experience empathetic grief with sites of death and macabre (Ashworth and Issacs, 2015), urban explorers experience empathetic grief with the neglect that buildings experience for their mundanity or unacknowledged industrial value. These buildings become metonyms of social activity, cultural significance and expressions of material culture that have been lost through the physical deterioration of the building. Earlier comments saw participants humanising buildings by using words like "heart" and "soul". This humanizing extends into understanding of a good death for a building as participants seek a peaceful and natural end to a building's biography. 


\section{Conclusions}

This study deepens our understanding of death in consumer culture.. Consumers draw on the vocabulary of death throughout their accounts of urban exploration and reveal experiences of loss and grief associated with the physical and cultural decline of buildings. This extends previous consumer research which often focuses on the death of people. Given Kaplan's (2008) suggestion that daily bombardment and proliferation of traumatic news images have created a culture of trauma, it is perhaps unsurprising that consumers extend the language of death into diverse contexts. An interdisciplinary body of theory has considered the agency and vitality of buildings in terms of their cultural, social and economic significance (Miles 2010; Maclaran and Brown 2005; Cairn and Jacobs 2015). Our findings contribute to this work by equally demonstrating the significance of the death of buildings.

Despite our findings revealing some similarities between human death and building death (e.g. the desire for a good death, feelings of grief), the divergences between the two are equally insightful. Interestingly, urban explorers generally have no prior relationship or attachment to the buildings before dereliction. Rather, they only come to know the building during the process of its physical dying. Unlike previous research on possession disposition which illustrates how divestment rituals associated with letting go can have a strong impact on the extended self (Hirschman, Ruvio and Belk 2012; Lastovicka and Fernandez 2005; Roster 2014), urban explorers are not tied to buildings through ownership or personal affiliation. Their emotions towards derelict buildings are driven by broader societal and cultural issues that go far beyond personal connections. From a theoretical perspective, this implies that obsolescence is not necessarily the end stage of consumer culture interactions, but can actually be the beginning of consumer fascination. Urban explorers are much more appreciative of desolate buildings than they are of those linked to urban vitality, a perspective that runs counter to a 
building's value being determined by capitalist interests. In their analysis of human-object relationships, Lanier et al. (2013) draw on the concepts of value and worth to illustrate how consumer assessments of an object's worth can transcend market value. For urban explorers, their interest in a building is not triggered when it is at the height of market value but rather when its market value has all but expired. At this point, the risk of the building's physical death brings its cultural worth to the fore. While Lanier et al. (2013) consider the relationship between value and worth within the context of more cherished possessions (children's toys as depicted in the Toy Story movies), we illustrate that a similar distinction may be relevant even for objects that are not part of the extended self. Consumer interest towards obsolete buildings cannot be explained in supply and demand terms as in limited edition products (Jang et al, 2015) or the market energy associated with the death of a celebrity (Radford and Bloch 2016). Indeed, such a value-oriented supply and demand perspective would overlook how it is worth (not value) that "gives life meaning" (Lanier et al. 2013, 37).

This may also extend our understanding of how material culture may be sustainably consumed. Connolly and Prothero (2003) critique the sustainability literature for being focussed upon recycling, where the unused becomes disposed and societal consumption patterns remain unchanged. Our findings show that material objects can be viewed differently by seeing worth in buildings beyond their primary economic purpose. Urban explorers counter the disposable nature of consumer culture, essentially extending useful life throughout the dying process.

We argue that consumers' fascination with derelict buildings can support their understanding of death and mortality more broadly. It is widely acknowledged that consumers do not like to think about or discuss death and refrain from consumer actions associated with planning for death (Levy 2015). A focus on the death of buildings allows for such otherwise suppressed thoughts and conversations to emerge. While contemplating one's own death or the 
death of loved ones may be accompanied by overpowering emotions, contemplation of the death of buildings provides the opportunity for acknowledging the impermanence of life and the inevitability of death. Kaplan (2008) conceptualises five degrees of trauma: (1) direct experience of trauma, (2) experiencing a relative in trauma, (3) the direct observation of trauma, (4) hearing the narrative of trauma and (5) mediated trauma such as viewing traumatic scenes in the media. For Stone (2012) dark tourism is a modern mediating institution that provides a social filter between life and death and is therefore akin to the least severe of Kaplan's degrees of trauma. Unlike dark tourism, the practices of urban exploration involve physical and haptic engagement with the materiality of decay in its unsanitised form. This closeness, more akin to Kaplan's (2008) direct observation of trauma, gives consumers greater ability to reflect on issues of death and mortality.

Death can be used "not as a physiological reality described metaphorically, but as itself a metaphor to describe other realities" as demonstrated by Walter $(2014,69)$ in relation to organisational death. Previous research has considered the distinction between physical death and social death for example, Sweeting and Gilhooly (1997) suggest that social death can precede physical death for dementia patients while Gabel (2016) distinguishes between physical death as an immediate end, and social death as an enduring process in an examination of online memorialisation practices. Our analysis of the death of buildings reveals cultural death to be equally worthy of exploration. As our findings demonstrate, the death of buildings has significance beyond physical and structural demise and is equally important from a cultural perspective. Previous work has explored how buildings can regenerate public spaces, offer spaces for consumption and in turn, reinforce cultural vitality (Miles 2010). Thus, the life of buildings can signal cultural life. We consider the alternative perspective: the death of buildings can signal cultural death. In our context cultural death is manifest in three ways: (1) cultural obsolescence where derelict buildings are at odds with contemporary practicalities and 
sensibilities, (2) loss of cultural places where complex historical narratives become forgotten, (3) loss of cultural skills where the architectural features are erased alongside a non-returnable end for associated skills and crafts. Whilst social death reflects a loss of social identity, loss of social connectedness and losses associated with bodily degeneration (Králová 2015), cultural death reflects a loss of material culture evidenced in lost activities, places, skills and cultural objects. Although important buildings and ruins are memorialised (Pétursdóttir 2012), the loss of more mundane ruins means that the collective memory becomes narrow and alternative voices which may be equally important to consumer culture become lost. This cultural death brings losses that are as significant as those associated with physical death of buildings. Emically our participants link these losses to a throwaway society and critique its associated values. From an etic perspective this reinforces Cairns and Jacob's (2015) discussion of capitalism's impact on what is considered as culturally important. We theorise the concept of cultural death to be an important contribution because it supports our understanding of the multi-dimensional nature of death in consumer culture.

This study opens up a number of avenues for future research. In demonstrating the broad value of a death studies lens, we suggest that this could be applied to other material and non-human entities, such as objects, art forms, social movements and places. We further consider that future research on the concept of cultural death may open up hidden perspectives on losses within consumer culture. 


\section{References}

Alderman, Derek H. 2002. "Writing on the Graceland wall: On the importance of authorship in pilgrimage landscapes." Tourism Recreation Research 27 (2):27-33.

Apel, Dora. 2015. Beautiful Terrible Ruins: Detroit and the Anxiety of Decline, New Brunswick, NJ: Rutgers University Press.

Appaduari, Arjun. 1986. The social life of things: Commodities in cultural perspective:

Cambridge: Cambridge University Press.

Aries, Philippe. 1974. Western Attitudes towards Death: From the Middle Ages to the Present. Baltimore: John Hopkins University Press.

Ashurst, John. 2007. Conservation of ruins. Routledge.

Ashworth, Gregory. J. and Rami K. Isaac. 2015. "Have we illuminated the dark? Shifting perspectives on 'dark' tourism.” Tourism Recreation Research 40(3): 316-325.

Augé, Marc. 2003. Le temps en ruines. Editions Galilée.

Baker, Courtney Nations, Stacey Menzel Baker and James W Gentry. 2016. "The role of body disposition in making sense of life and death" In S. Dobsha Ed. Death in a Consumer Culture, , London,: Routledge 213-227

Beech, John. 2000. "The enigma of holocaust sites as tourist attractions-the case of Buchenwald." Managing Leisure 5, (1): 29-41.

Bennett, Jane. 2004. "The force of things: steps towards an ecology of matter." Political Theory 32: 347-372. 
Benjamin, Walter. 1999. The Arcades Project, trans. Howard Eiland and Kevin Mclaughlin. Cambridge: Belknap Press of Harvard University Press.

Benton, Raymond. 2014. "Reduce, Reuse, Recycle... and Refuse.” Journal of Macromarketing 35(1):111-122. Biran, Avital., Yaniv Poria. and Gila Oren. 2011. "Sought experiences at (dark) heritage sites."Annals of Tourism Research 38(3): 820-841.

Bury, Michael. 1982. "Chronic illness as biographical disruption.” Sociology of Health and Illness 4(2):167-82.

Cairns, Stephen. and Jane M. Jacobs. 2010. Buildings Must Die: A Perverse View of Architecture. Mass: MIT Press.

Carr, Deborah. 2012. "Death and dying in the contemporary United States: What are the psychological implications of anticipated death?." Social and Personality Psychology Compass 6.2: 184-195.

Chang, T. C. and Shirlena Huang. 2005. "Recreating place, replacing memory: Creative destruction at the Singapore River.” Asia Pacific Viewpoint 46: 267-280

Chronis, Athinodoros., Eric J. Arnould and Ronald D. Hampton. 2012. “Gettysburg reimagined: the role of narrative imagination in consumption experience." Consumption Markets \& Culture 15(5): 261-286.

Connolly, John., and Andrea Prothero, 2003. "Sustainable consumption: comnsumption, consumers and the commodity discourse." Consumption, Markets and Cutlure 6(4):275-291.

Connolly, Tristanne. 2011. Spectacular Death: Interdisciplinary Perspectives on Mortality and (Un)representability. Chicago: The University of Chicago Press. 
Coombs, Maureen. 2015. “A scoping review of family experience and need during end of life care in intensive care." Nursing Open 2.1: 24-35.

Crawford, James. 2015. Fallen Glory the lives and deaths of twenty lost buildings from the tower of Babel to the twin towers. London,:Old Street Publishing

De Coverly, Edd, Pierre McDonagh, Lisa O’Malley and Maurice Patterson. 2008. "'Hidden Mountain: The Social Avoidance of Waste.'” Journal of Macromarketing, 28(3):289-303.

Derrida, Jacques. 1994. Specters of Marx: The State of the Debt, the Work of Mourning and New International, Trans. Peggy Kamuf, New York: Routledge.

Degen, Monica. and Kevin Hetherington. 2001. "Guest editorial: hauntings.” Space and Culture, 11/12:1-6.

Diderot, Denis. 1995 [1767]. 'Le salon de 1767’. In John Goodman (ed.) Diderot on Art, trans. John Goodman, New Haven, CT and London: Yale University Press.

Edensor, Tim. 2005a. Industrial Ruins: Space, Aesthetics and Materiality, Oxford: Berg. Edensor, Tim. 2005b. "The ghosts of industrial ruins: ordering and disordering memory in excessive space.” Environment and Planning D: Society and Space 23: 829-849.

Edensor, Tim. 2005c. "Waste matter - the debris of industrial ruins and the disordering of the material world.” Journal of Material Culture 10: 311-332.

Edwards, Justin. 2016. Dark Tourism: Death, Disaster, Suffering, in Routledge Companion to Travel Writing, Routledge Companion Series, London: Routledge: 1-19.

Epp, Amber M. and Linda L. Price, 2010. “The Storied Life of Singularized Objects: Forces 
of Agency and Network Transformation, Journal of Consumer Research 36(5): 820-837.

Foley, Malcolm. and John J. Lennon, 1996. “Editorial: Heart of darkness.” International Journal of Heritage Studies 2(4): 195-197.

Gabel, Terrance G. 2016. "Cheating death via social self immortalization The potential of consumption-laden online memorialization to extend and link selves beyond (physical) death.” In Death in a Consumer Culture, edited by Susan Dobscha, 137-154. London: Routledge.

Garrett, Bradley L. 2011. “Assaying history: creating temporal junctions through urban exploration.” Environmental and Planning D: Society and Space 29:1048-1067.

Garrett, Bradley L. 2013. "Undertaking recreational trespass: urban exploration and infiltration." Transactions of the Institute of British Geographers 39(1):1-13.

Glaser, Barney. G. 1965. "The constant comparative method of qualitative analysis.” Social problems, 12(Spring):436-445.

Godfrey, Richard. and Simon Lilley. 2009. "Visual consumption, collective memory and the representation of war." Consumption Markets \& Culture 12 (4): 275-300.

Gregson, Nicky., Helen Watkins and Melania Calestani. 2010. "Inextinguishable fibres: demolition and the vital materialisms of asbestos." Environment and Planning A 42 (5): 1065-1083.

Hackley, Rungpaka Amy and Chris Hackley. 2016. "Death, Ritual and Consumption in Thailand: Insights from The Pee Ta Kohn Hungry Ghost Festival." In Death in a Consumer Culture, edited by Susan Dobscha, 91-107. London: Routledge. 
Hartmann, Rudi. 2014. "Dark tourism, thanatourism and dissonance in heritage tourism management: New directions in contemporary tourism research.” Journal of Heritage Tourism 9(2): 166-182.

Harvey, David. 1975. The Political Economy of Urbanization in Advanced Capitalist Societies: The Case of the United States. In The Social Economy of the City. ed. Gary Gappert and Harold M. Rose, 119-164. Beverly-Hills: Sage Urban Affairs Annual Review 9. Heisley, Deborah D. and Sidney J. Levy. 1991. "Autodriving: A Photoelicitation Technique.” Journal of Consumer Research 18 (3): 257-272.

Heyl, B. S. 2008. Ethnographic Interviewing, In P. Atkinson, A. Coffey, S. Delmont, J. Lofland, and L. Lofland (eds) Handbook of Ethnography, London: Sage Publications Ltd. Hetherington, Kevin. 2004. "Secondhandedness: consumption, disposal, and absent presence." Environment and Planning D 22 (1):157-174.

Hill, Mark E. and Jane Cromatie. 2004. "The which is "not": Forgetting." Consumption Markets \& Culture 7 (1): 69-98.

Hirschman, Elizabeth C., Ayalla Ruvio and Russell W. Belk. 2012. "Exploring space and place in marketing research: excavating the garage." Marketing Theory 12 (4): 369-389. Hollis, Edward. 2009. The Secret Life of Buildings: From The Parthenon To The Vegas Strip In Thirteen Stories. London: Portobello Books.

Holt, Douglas. B. 1997. "Poststructuralist Lifestyle Analysis: Conceptualizing the Social Patterning of Consumption in Postmodernity." Journal of Consumer Research 23(4): 326350. 
Huyssen, Andreas. 2010. "Authentic ruins.” In Julia Hell and Andreas Schönle Ruins of Modernity 17-28, London: Duke University Press.

Jang, Wonseok Eric, Yong Jae Ko, Jon D. Morris, and Yonghwan Chang. 2015. "Scarcity Message Effects on Consumption Behavior: Limited Edition Product Considerations." Psychology \& Marketing 32 (10):989-1001.

Kaplan, Ann E. 2008. "Global trauma and public feelings: Viewing images of catastrophe." Consumption Markets \& Culture 11(1): 3-24.

Kozinets, Robert V. 2015. Netnography. John Wiley \& Sons, Inc.

Králová, Jana. 2015. “What is social death?” Contemporary Social Science: Journal of the Academy of Social Sciences 10(3): 235-248.

Laclau, Ernesto. 1995. “The Time is our of Joint.” Diacritics 25 (2):85-96. Lanier Jr, Clinton D., C. Scott Rader, and Aubrey R. Fowler III. 2013. “Anthropomorphism, marketing relationships, and consumption worth in the Toy Story trilogy.” Journal of Marketing Management 29(1-2): 26-47.

Lastovicka, John L., and Karen V. Fernandez. 2005. "Three paths to disposition: The movement of meaningful possessions to strangers." Journal of Consumer Research 31(4): 813-823.

Leary, John Patrick. 2011. Detroitism, Guernica, published online January 2011, Available From: https://www.guernicamag.com/features/leary_1_15_11/ [26/04/16]

Lennon, John J. and Malcolm Foley. 2000. Dark tourism. Cengage Learning EMEA. 
Levy, Sidney J. 2015. "Olio and integraphy as method and the consumption of death." Consumption Markets \& Culture 18(2): 133-154.

Lorimer, Hayden. and Simon Murray 2015. "The Ruin in Question.” Performance Research 20(3): 58-66.

Lynch, Kevin. 1972. What Times is this Place? Cambridge, MA: MIT Press.

Maclaran, Pauline and Stephen Brown. 2005. "Consuming the Utopian marketplace." Journal of Consumer Research 32 (2): 311-323.

Page, Max. 2001. The creative destruction of Manhattan, 1900-1940. University of Chicago Press.Masson, John D. 2002 "Non-professional understands of a good death". Mortality 7(2):191-209.

Miles, Matthew B., and A. Michael Huberman. 1994. Qualitative data analysis: An expanded sourcebook. Sage.

Miles, Steven. 2010. Spaces for Consumption. London: Sage.

Miljković, Milos D., Dennis Emuron, Lori Rhodes, Joseph Abraham, and Kenneth Miller, 2015. "Allow Natural Death" versus "Do Not Resuscitate": What Do Patients with Advanced Cancer Choose? Journal of Palliative Medicine 18(5): 457-460.

Lim, Ming. and James Fitchett 2011. “Agency, Objects and the Dead: Can Consumer Culture Speak?" In Advances in Consumer Research-European Conference Proceedings 9: 611-612.

Muzaini, Hamzah., Peggy Teo. and Brenda S. A. Yeoh. 2007. "Intimations of postmodernity in dark tourism: The fate of history at Fort Siloso, Singapore."Journal of Tourism and Cultural Change 5(1): 28-45. 
Ninjalicious, 2005. Access All Areas: a user's guide to the art of urban exploration, Coach House Books.

O’Donohoe, Stephanie. 2015. “Consuming Childhood Grief.” In Consumer Vulnerability: Conditions, Contexts and Characteristics, edited by Kathy Hamilton, Susan Dunnett and Maria Piacentini, 89-102. London: Routledge.

Parsons, Liz. and Pauline Maclaran. 2009. “Editorial 'Unpacking disposal': introduction to the special issue." Journal of Consumer Behaviour 8 (Nov-Dec):301-304.

Pétursdóttir, Pora. 2012. "Concrete matters: Ruins of modernity and the things called heritage.” Journal of Social Archaeology 13(1):31-53.

Pétursdóttir, Póra, and Bjørnar Olsen. 2014. "Imaging modern decay: the aesthetics of ruin photography." Journal of Contemporary Archaeology 1 (1): 7-23.

Podoshen, Jeffery S. and James M. Hunt. 2009. “Animosity, collective memory, rumor and equity restoration: Consumer reactions to the Holocaust, Consumption Markets \& Culture 12(4): 301-327.

Podoshen, Jeffrey S. 2013. "Dark tourism motivations: Simulation, emotional contagion and topographic comparison." Tourism Management 35: 263-271.

Podoshen, Jeffrey S., Vivek Venkatesh, Jason Wallin, Susan A. Andrzejewski, and Zheng Jin. 2015. "Dystopian dark tourism: An exploratory examination.” Tourism Management 51: 316-328. 
Radford, Scott K., and Peter H. Bloch. 2012 "Grief, commiseration, and consumption following the death of a celebrity." Journal of Consumer Culture 12 (2): 137-155.

Rojek, Chris. 1993. Ways of Escape, Basingstoke: Macmillan.

Roster, Catherine A. 2014. "The art of letting go: creating dispossession paths towards an unextended self." Consumption Markets \& Culture 17 (4): 321-345.

Ryberg-Webster, Stephanie and Kelly L. Kinahan, 2014. "Historic preservation and urban revitalization in the twenty-first century.” Journal of Planning Literature 29 (2):119-139.

Schwartz, Barry. 2009. "Collective forgetting and the symbolic power of oneness: The strange apotheosis of Rosa Parks.” Social Psychology Quarterly 72(2): 123-142.

Seale, Clive and Sjaak van der Geest. 2004. "Good and bad death: Introduction. Social Science and Medicine 58 (5): 883-885.

Seaton, Anthony V. 1996. "Guided by the dark: From thanatopsis to thanatourism." International Journal of Heritage Studies 2(4 ): 234-244.

Shanks, Michael. 2014. 'Ruins - Thoughts on the Aesthetic,' All Things Archaeological [Online], Available: www.mshanks.com/2014/04/02/ruins-thoughts-on-the-aesthetic/

Simmel, Georg. 1959. The Ruin, In K. H. Wolff (ed.), Georg Simmel, 259-266, Columbus: The Ohio State Univeristy Press.

Spradley, J. P. 1979. The Ethnographic Interview. New York: Holt, Rinehart and Winston.

Starn, Randolph. 2002. "Authenticity and historic preservation: towards an authentic history." Hisotry of human sciences 15 (1):1-16. 
Stone, Philip. and Richard Sharpley. 2008. "Consuming Dark Tourism: A Thanalogical Perspective." Annals of Tourism Research 35(2): 574-595.

Stone, Philip. 2012. "Dark tourism and significant other death: Towards a model of mortality mediation." Annals of Tourism Research 39(3): 1565-1587.

Stone, Philip. and Richard Sharpley. 2013. Deviance, dark tourism and 'dark leisure': towards a (re)configuration of morality and the taboo in secular society, in S. Elkington and S. Gammon (Eds.) Contemporary perspectives in leisure: Meanings, motives and lifelong learning, Abington: Routledge.

Strange, Carolyn. and Michael Kempa. 2003. "Shades of Dark Tourism: Alcatraz and Robben Island." Annals of Tourism Research 30(2): 386-405.

Stoler, Ann Laura. 2008. "Imperial debris: reflections on ruins and ruination." Cultural Anthropology 23(2):191-219.

Sweeting, Helen and Mary Gilhooly. 1997. "Dementia and the phenomenon of social death." Sociology of Health \& Illness 19 (1): 93-117.

Taussig, Michael. 2003. Miasma. In Gay Hawkins and Stephen Muecke (ed.) Culture and Waste: The Creation and Destruction of Value, 9-23. Lanham, MD: Rowman and Littlefield.

Tinson, Julie. S., Michael A. J. Saren., and Bridget E. Roth. 2015. "Exploring the role of dark tourism in the creation of national identity of young Americans." Journal of Marketing Management, 31(7-8): 856-880.

Truog, Robert D and Franklin G Miller. 2014. "Defining death: the importance of scientific candor and transparency." Intensive care medicine 40:885-887 
Turley, Darach and Stephanie O'Donohoe. 2013. "Fare-Well Strategies: Caring Consumption as Part of the 'Good Death'." In European Advances in Consumer Research Volume 10, edited by Gert Cornelissen, Elena Reutskaja, and Ana Valenzuela, 316-317. Duluth, MN : Association for Consumer Research.

Visconti, Luca M., John F. Sherry, Stefania Borghini, and Laurel Anderson. 2010 "Street art, sweet art? Reclaiming the "public" in public place." Journal of Consumer Research 37(3): 511-529.

Wakeman, Rosemary. 2007 "Fascinating Les Halles.” French Politics, Culture \& Society, 25(2): 46-72.

Walter, Tony. 2014. "Organizations and death - a view from death studies." Culture and Organization 20 (1): 68-76.

Warnaby, Gary. 2013. "Synchronising retail and space: using urban squares for competitive place differentiation." Consumption Markets \& Culture 16 (1): 25-44. 